\title{
Motivasi Petani Mengikuti Program Asuransi Usahatani Padi di Kabupaten Lampung Tengah
}

\author{
Motivation of Farmers Following Rice Farming Insurance Program \\ in Central Lampung District
}

\author{
Oleh: \\ Sapitri Anggitia Putri ${ }^{1 *}$, Sumaryo Gitosaputro ${ }^{2}$, Yuniar Aviati Syarief ${ }^{2}$ \\ ${ }^{1}$ Dinas Ketahanan Pangan, Tanaman Pangan dan Hortikultura Provinsi Lampung, \\ ${ }^{2}$ Program Studi Magister Penyuluhan dan Komunikasi Pertanian, Fakultas Pertanian, Universitas Lampung, \\ *e-mail: kanjeng.anggi23@gmail.com
}

Received May 29, 2020; Revised June 28, 2020; Accepted June 29, 2020

\begin{abstract}
ABSTRAK
Penelitian ini bertujuan untuk menganalisis fator-faktor yang mempengaruhi motivasi petani mengikuti program AUTP dan kendala yang dihadapi oleh petani selama menjadi peserta AUTP. Penelitian dilaksanakan di Kecamatan Gunung Sugih, Pubian dan Trimurjo Kabupaten Lampung Tengah pada bulan Desember 2019. Penentuan lokasi penelitian menggunakan teknik purposive sampling. Responden penelitian adalah petani yang mengikuti program AUTP yang berjumlah 88 petani. Analisis yang digunakan adalah Analisis Jalur (Path Analysis). Hasil penelitian menunjukkan bahwa motivasi internal petani masuk kategori tinggi dengan $45,45 \%$, yaitu dorongan petani untuk ikut serta pada program AUTP karena keinginan sendiri dengan pertimbangan adanya jaminan atas risiko kerusakan yang dialami. Adapun faktor-faktor yang secara langsung mempengaruhi motivasi petani mengikuti program AUTP yaitu tingkat pengetahuan informasi AUTP dan intensitas pendampingan. Sementara variabel tingkat pengetahuan pengetahuan informasi AUTP secara tidak langsung berpengaruh terhadap keikutsertaan petani melalui tingkat motivasi petani mengikuti program AUTP. Kendala yang dihadapi oleh peserta AUTP meliputi lamanya proses pengajuan klaim dan pencairan dana klaim (pertanggungan).
\end{abstract}

Kata kunci: analisis jalur, AUTP, motivasi, petani

\begin{abstract}
This study aims to analyze the factors which affects the motivation of farmers to take part in the AUTP program and the obstacles encountered during being an AUTP participant. The study was conducted in Gunung Sugih, Pubian and Trimurjo subdistricts, Central Lampung District. Determination of the location of the study using purposive sampling technique. The study population was farmers who participated in the AUTP program, amounting to 88 farmers. This research was conducted in December 2019. The analysis used was Path Analysis. The results showed that the internal motivation of farmers in the high category with a percentage of 45.45 percent, namely the encouragement of farmers to participate in the AUTP program because of their own desire to consider the existence of collateral for the risk of damage experienced. The factors that directly influence the motivation of farmers to participate in the AUTP program are the level of knowledge of AUTP information and the intensity of mentoring. While the variable level of knowledge of AUTP information knowledge indirectly affects the participation of farmers through the level of motivation of farmers participating in the AUTP program Constraints faced by AUTP participants include the duration of the process of filing claim and disbursing claims funds (coverage).
\end{abstract}

Keywords: path analysis, AUTP, motivation, farmer 


\section{PENDAHULUAN}

Indonesia merupakan negara agraris yang sebagian besar penduduknya bergantung pada beras sebagai makanan pokok. Peran pemerintah sangat diperlukan dalam upaya peningkatan produksi padi petani untuk mewujudkan swasembada pangan khususnya beras. Program pemerintah dalam upaya memenuhi kebutuhan pangan nasional khususnya beras terus menerus dilakukan melalui inovasi teknologi dan penerapan program perbaikan manajemen usahatani mengingat beras sebagai bahan pangan pokok bagi rakyat Indonesia. Upaya Pemerintah khususnya Kementerian Pertanian untuk mensukseskan pencapaian target swasembada pangan merupakan tujuan utama yang melibatkan semua pihak. Berkenaan dengan hal tersebut, sejak tahun 2015 pemerintah melaksanakan Upaya Khusus (UPSUS) swasembada padi dengan target produksi padi tahun 2016 mencapai 75,13 juta ton.

Tahun 2015 produksi padi di Provinsi Lampung sebesar 3.641.895 ton GKG dan meningkat di tahun 2016 menjadi 4.020.420 ton GKG atau sebesar 10,39 persen (Dinas Tanaman Pangan dan Hortikultura Provinsi Lampung, 2018). Peningkatan produksi padi di Provinsi Lampung dikarenakan dukungan banyak pihak mulai dari pemerintah pusat, daerah sampai pada pelaku utama yaitu petani. Fokus pemerintah terhadap pencapaian swasembada padi terus berlanjut, pada tahun 2017 produksi padi di Provinsi Lampung sebesar 4.324.445 ton GKG atau meningkat sebesar 7,56 persen dibanding tahun 2016 . Peningkatan produksi padi selama 5 (lima) tahun terakhir (rata-rata peningkatan 7,32 persen) menjadikan Provinsi Lampung memiliki keunggulan di sektor pertanian. Usaha di sektor pertanian, khususnya usahatani padi dihadapkan pada risiko ketidakpastian sebagai akibat dampak negatif perubahan iklim yang merugikan petani.

Mengingat hal tersebut di atas, maka diperlukan cara untuk mengatasi kerugian yang dialami petani, sehingga pemerintah membantu mengupayakan perlindungan dalam bentuk asuransi pertanian sebagaimana tercantum pada UndangUndang Nomor 9 tahun 2013 tentang Perlindungan dan Pemberdayaan Petani yang telah ditindaklanjuti dengan penerbitan Peraturan Menteri Pertanian Nomor 40 tahun 2015 tentang Fasilitasi Asuransi Pertanian (Kementerian Pertanian, 2017). Asuransi ini sebagai alat untuk mengelola risiko dan berperan penting dalam mengatur atau mengurangi risiko. Salah satu program pemerintah yang menjadi sarana untuk membantu petani dalam hal penanganan risiko kerusakan akibat banjir, kekeringan, serangan hama dan penyakit (OPT) adalah Asuransi Usaha Tani Padi (AUTP) yang sudah berjalan sejak tahun 2015 .

Dari alokasi yang telah diberikan oleh pemerintah, pada kenyataannya realisasi di lapangan tidak sesuai dengan alokasi yang diberikan karena tidak semua petani di kabupaten/kota se Provinsi Lampung khususnya Kabupaten Lampung Tengah mengikuti program AUTP. Naik turunnya minat petani di kabupaten Lampung Tengah selama tahun 2015-2018 mengikuti program AUTP berpengaruh pada realisasi alokasi anggaran yang telah diberikan oleh pemerintah khususnya Kementerian Pertanian RI. Dilihat dari tahun 2015, luasan lahan yang terdaftar AUTP di Provinsi Lampung mengalami peningkatan selama empat tahun terakhir. Hal tersebut menunjukkan bahwa petani padi di Provinsi Lampung semakin berminat untuk mengikuti program AUTP dan semakin merasakan manfaat yang diterima. Oleh karena itu, perlu dikaji lebih dalam faktorfaktor apa saja yang mempengaruhi motivasi petani mengikuti program AUTP dalam menanggulangi risiko gagal panen terutama di Kabupaten Lampung Tengah yang merupakan Kabupaten sentra untuk tanaman padi.

Motivasi merupakan kekuatan internal yang menyebabkan seseorang melakukan suatu tindakan. Motivasi dapat mengetahui perilaku serta keinginan yang sesuai dengan 
budaya setiap individu. Motivasi sebagai proses psikologi timbul diakibatkan oleh faktor di dalam diri seseorang itu sendiri yang disebut intrinsik atau faktor diluar diri yang disebut ekstrinsik (Wahjosumidjo, 1987; Listiana et al. 2020). Keikutsertaan petani dalam Program Asuransi Usahatani Padi sangat dipengaruhi oleh faktor-faktor baik dari dalam maupun dari luar sehingga perlu dikaji lebih lanjut faktor-faktor apa saja yang mempengaruhi petani mengikuti program AUTP di Kabupaten Lampung Tengah.

\section{METODE PENELITIAN}

Penetapan lokasi pada penelitian ini dilakukan secara sengaja (purposive sampling) yaitu sampel ditetapkan secara sengaja oleh peneliti didasarkan atas kriteria atau pertimbangan tertentu (Mardikanto dan Irianto, 2010). Alasan yang melatarbelakangi Kabupaten Lampung Tengah dijadikan sebagai lokasi penelitian yaitu karena Kabupaten Lampung Tengah memiliki potensi lahan sawah tertinggi (pada tahun 2017 sebesar 82.245 hektar) diantara Kabupaten yang lainnya serta merupakan Kabupaten yang memiliki produksi padi cukup tinggi pada tiga tahun terakhir. Populasi penelitian adalah kelompok tani yang terdapat di tiga kecamatan (Gunung Sugih, Pubian dan Trimurjo) yang terdapat di Kabupaten Lampung Tengah yang mengikuti Program AUTP.

Metode yang digunakan dalam penelitian ini adalah metode survei, yaitu pengambilan sampel penelitian dari anggota populasi. Data yang digunakan dalam penelitian ini meliputi data primer dan data sekunder. Data primer diperoleh melalui wawancara langsung dengan anggota kelompok tani di Kabupaten Lampung Tengah yang mengikuti Program AUTP dengan menggunakan kuesioner. Data sekunder dikumpulkan melalui studi pustaka seperti buku, literatur, sumber bacaan lain, maupun media elektronik (internet). Data sekunder juga diperoleh dari Dinas
Tanaman Pangan dan Hortikultura Provinsi Lampung, Dinas Pertanian Tanaman Pangan dan Hortikultura Kabupaten Lampung Tengah, Badan Pusat Statistik Provinsi Lampung, Badan Pusat Statistik Kabupaten Lampung Tengah dan Jasindo serta instansi lain yang terkait dengan penelitian ini.

Analisis data yang digunakan pada penelitian ini adalah Uji instrumen meliputi uji validitas dan reliabilitas. Uji prasyarat meliputi uji normalitas, multikolinieritas dan heteroskedasitas. Analisis deskriptif dan analisis jalur (path analysis).

\section{HASIL DAN PEMBAHASAN}

\section{Keadaan Umum Peserta AUTP}

\section{Umur peserta AUTP}

Berdasarkan data yag diperoleh dari lapangan terlihat bahwa peserta AUTP dengan usia 32-43 tahun berjumlah 32 orang, 44-45 tahun 39 orang, 56-67 tahun 11 orang dan 68-79 tahun berjumlah 6 orang. Dari data tersebut diketahui bahwa jumlah peserta AUTP yang berumur 44-55 tahun memiliki jumlah yang paling banyak yaitu 39 orang atau 44,32 persen dari jumlah keseluruhan peserta AUTP. Berdasarkan Badan Pusat Statistik (2014), umur dikelompokkan menjadi tiga kelompok yaitu belum produktif (0-14 tahun), umur produktif (15-64 tahun) dan tidak produktif lagi (diatas 65 tahun). Hasil penelitian menunjukkan bahwa petani yang mengikuti AUTP masuk dalam kelompok usia produktif (44-45 tahun) dengan persentase 44,32 persen, sehingga sangat berpengaruh pada tingkat penerimaan dan pemahaman informasi terutama mengenai AUTP.

\section{Tingkat pendidikan formal peserta AUTP}

Hasil data dari lapangan menunjukkan bahwa jumlah peserta AUTP yang memiliki pendidikan terakhir SD berjumlah 18 orang, SMP sebanyak 26 orang, SMA 37 orang dan lainnya terdiri dari tidak sekolah sebanyak 6 orang dan jenjang D1 bidang komputer 
hanya satu orang. Mayoritas pendidikan peserta AUTP yang mengikuti program AUTP di Kabupaten Lampung Tengah adalah SMA dengan jumlah 37 orang (42,00 persen). Keadaan ini menunjukkan peserta AUTP mayoritas memiliki kemampuan untuk mengerti dan menerima informasi dengan baik sehingga dapat menunjang dan mempelancar komunikasi antara petani dengan penyuluh pertanian lapangan (PPL) dalam memberikan informasi/ sosialisasi mengenai program AUTP.

\section{Karakteristik Peserta AUTP}

\section{Status kepemilikan lahan}

Hasil penelitian menunjukkan bahwa peserta AUTP yang memiliki status sebagai pemilik lahan usahatani berjumlah 49 orang (luas lahan 61,27 hektar) dengan persentase paling tinggi yaitu sebesar 55,68 persen, dan petani penggarap lahan usahatani berjumlah 21 orang (lahan seluas 38,50 hektar) dengan persentase sebesar 23,86 persen dari jumlah responden keseluruhan. Pada penelitian ini status kepemilikan lahan tidak ada pengaruhnya dengan tingkat motivasi petani karena baik petani dengan status milik sendiri, penggarap, penyewa dan penyakap mereka tetap terdorong untuk mengikuti program AUTP

\section{Luas lahan}

Peserta AUTP yang memiliki luas lahan garapan $<0,5$ hektar berjumlah 39 orang dengan persentase 44,32 persen, petani dengan luas lahan garapan 0,5-1 hektar berjumlah 33 orang dan petani dengan luas garapan 1,1-1,5 hektar berjumlah 16 orang. Hasil penelitian menggambarkan bahwa target pemerintah untuk membantu petani padi yang memiliki lahan usahatani yang sempit $(<2$ hektar) tercapai, dengan harapan apabila petani mengalami kerugian akibat kerusakan petani mendapatkan modal usaha untuk tetap menjalankan usahatani pada musim tanam selanjutnya. Semakin luas lahan garapan yang diusahakan petani, maka akan semakin besar produksi yang dihasilkan seiring dengan pengolahan yang baik akan menghasilkan pendapatan yang besar Soekartawi (1999). Pada penelitian ini sebagian besar petani memiliki lahan sempit, meskipun demikian petani merasa optimis dengan keberhasilan usahatani yang mereka jalankan sehingga kecil kemungkinan untuk mengalami kegagalan panen akibat kerusakan, selain itu petani yang memiliki lahan sempit maupun luas mempunyai kesempatan yang sama untuk ikut serta pada program AUTP.

\section{Pengalaman Usahatani}

Pada penelitian ini pengalaman usahatani dinilai dengan indikator lamanya petani tergabung dalam kelompok tani dan lamanya menjalankan usahatani padi. Sebanyak 51 petani peserta AUTP termasuk dalam kategori sangat berpengalaman dengan persentase 57,95 persen dan sebanyak 20 petani peserta masuk ke dalam kategori berpengalaman dengan persentase 22,73 persen. Berdasarkan Soehardjo dan Patong (1999), Petani yang sudah lama berusahatani memiliki tingkat pengetahuan, pengalaman dan keterampilan yang tinggi dalam menjalankan usahatani. Hal tersebut sejalan dengan hasil penelitian yang dilakukan bahwa petani responden sebagian besar masuk kategori sangat berpengalaman sehingga mampu dan mau menerapkan inovasi dan informasi baru dengan ikut serta menjadi anggota AUTP.

\section{Tingkat pengetahuan peserta AUTP}

Berdasarkan hasil data dari lapangan diketahui bahwa peserta AUTP memiliki karakteristik pemahaman yang berbeda mengenai penerimaan informasi AUTP. Petani peserta AUTP yang sangat paham mengenai informasi AUTP berjumlah 13 orang dengan persentase 14,77 persen dan 30 orang yang paham mengenai informasi AUTP dengan persentase tertinggi yaitu 34,09 persen. 


\section{Tingkat pemenuhan persyaratan AUTP}

Hasil penelitian dilapangan, peserta AUTP berjumlah 48 orang dengan persentase tertinggi sebesar 54,55 persen, merasa mudah memenuhi persyaratan untuk menjadi peserta AUTP. Sebesar 35 orang petani responden $(39,77$ persen) merasa sulit untuk memenuhi persyaratan menjadi peserta AUTP, hal ini dikarenakan petani beranggapan bahwa untuk menjadi perserta AUTP ada beberapa tahapan yang harus dilewati seperti penilaian dari pihak asuransi apakah layak atau tidak petani menjadi peserta AUTP.

\section{Besaran premi AUTP}

Hasil data di lapangan diketahui bahwa sebanyak 52 orang peserta AUTP menganggap besaran premi AUTP yang dikeluarkan termasuk kategori sedang dan 30 petani peserta beranggapan besaran premi yang dikeluarkan tergolong kecil, hal ini dikarenakan sumber premi yang dikeluarkan selain dari subsidi pemerintah sebesar Rp. 144.000/ha/MT, petani responden mendapat sumber dana dari simpanan wajib /iuran kelompok tani yang digunakan untuk membantu membayar premi sehingga sisa pembayaran premi yang mereka keluarkan secara pribadi masih tergolong kecil.

Tingkat kesesuaian jumlah pertanggungan AUTP

Hasil penelitian diperoleh bahwa sebanyak 68 peserta AUTP menjawab jumlah pertanggungan yang diterima sangat sesuai. Berdasarkan wawancara di lapangan, uang pertanggungan yang diterima oleh petani dipergunakan untuk keperluan budidaya musim tanam berikutnya seperti modal olah tanah, untuk pembelian benih dan pupuk. Sebanyak empat peserta AUTP beranggapan bahwa dana klaim atau pertanggungan yang diterima sangat tidak sesuai. Hal tersebut dikarenakan selain keperluan budidaya, petani juga mempergunakan untuk keperluan rumah tangga seperti untuk biaya makan, sekolah anak dan membayar hutang piutang yang dipergunakan untuk proses budidaya musim tanam sebelumnya sehingga tidak cukup dipergunakan untuk modal budidaya musim tanam selanjutnya.

\section{Intensitas pendampingan}

Pada penelitian ini intensitas pendampingan dilihat berdasarkan kuantitas pendampingan dengan melihat frekuensi pendampingan dan lamanya pendampingan yang dilakukan oleh penyuluh kepada petani dan berdasarkan kualitas pendampingan dengan melihat tingkat pemahaman petani terhadap program AUTP. Berdasarkan hasil penelitian di lapangan bahwa pendampingan AUTP yang dilakukan oleh petugas lapangan terutama penyuluh terhadap petani responden masuk kedalam kategori cukup dengan persentase 50,00 persen. Sosialisasi mengenai AUTP hanya dilakukan satu kali dalam satu tahun dan pendampingan kepaa petani dilakukan paling banyak empat kali dalam tiap musim atau tiap program AUTP dilaksanakan.

\section{Tingkat motivasi petani AUTP}

Hasil penelitian menunjukkan bahwa tingkat motivasi internal petani termasuk dalam kategori tinggi dengan persentase 45,45 persen. Hal tersebut menunjukkan bahwa dorongan yang berasal dari diri petani untuk mengikuti program AUTP karena adanya jaminan ganti rugi terhadap risiko kegagalan yang dihadapi, sehingga petani merasa yakin untuk ikut serta pada program AUTP. Tingkat motivasi eksternal petani mengikuti program AUTP termasuk pada kategori sedang dengan jumlah persentase petani reponden 54,55 persen.

\section{Keikutsertaan petani pada program AUTP}

Berdasarkan hasil penelitian, petani yang ikut serta pada program AUTP termasuk dalam kategori tinggi dengan 
persentase sebesar 52,27 persen dan sangat tinggi dengan persentase 21,59 persen.

Berdasarkan Tabel output AMOS di atas, nilai $\mathbf{P}$ value 0,000 pada $\mathrm{P}$ (Probability Value) menunjukkan angka yang sangat kecil (lebih kecil dari 0,01) dengan demikian dapat disimpulkan bahwa intensitas pendampingan berpengaruh terhadap tingkat motivasi petani. Berdasarkan koefisien jalur yang terbentuk, koefisien jalur intensitas pendampingan terhadap tingkat motivasi petani bertanda positif $(0,449)$ yang berarti pengaruh intensitas pendampingan terhadap tingkat motivasi bersifat positif, yaitu semakin tinggi intensitas pendampingan maka tingkat motivasi petani juga akan semakin tinggi begitu juga sebaliknya.

Tabel 1.

Output analisis jalur dengan Amos 25

\begin{tabular}{lllrrl}
\hline & \multicolumn{5}{c}{$\begin{array}{c}\text { Koefisien } \\
\text { jalur }\end{array}$} \\
\hline Y & $<--$ & X1 & 0,133 & 0,339 & Tidak signifikan \\
Y & $<--$ & X3 & 0,037 & 0,623 & Tidak signifikan \\
Y & $<--$ & X4 & $\mathbf{- 0 , 1 0 8}$ & $\mathbf{0 , 0 1 4}$ & Signifikan \\
Y & $<--$ & X5 & $-0,024$ & 0,83 & Tidak signifikan \\
Y & $<--$ & X6 & $\mathbf{- 0 , 1 6 3}$ & $\mathbf{0 , 2 2 1}$ & Signifikan \\
Y & $<--$ & X7 & 0,037 & 0,693 & Tidak signifikan \\
Y & $<--$ & X8 & $\mathbf{0 , 4 4 9}$ & $\mathbf{0 , 0 0 0}$ & Signifikan \\
Y & $<--$ & X2 & $-0,045$ & 0,737 & Tidak signifikan \\
Z & $<--$ & X4 & $\mathbf{0 , 7 6 7}$ & $\mathbf{0 , 0 0 0}$ & Signifikan \\
Z & $<--$ & Y & $-0,007$ & 0,961 & Tidak signifikan \\
Z & $<--$ & X3 & $-0,127$ & 0,28 & Tidak signifikan \\
\hline
\end{tabular}

Tingkat pengetahuan peserta AUTP berpengaruh terhadap keikutsertaan petani. Terhadap program AUTP yang ditunjukkan dengan nilai $\mathrm{P}$ value 0,000 pada $\mathrm{P}$ (Probability Value). Berdasarkan koefisien jalur yang terbentuk, koefisien jalur tingkat pengetahuan responden terhadap keikutsertaan petani terhadap program AUTP bertanda positif $(0,767)$ yang berarti pengaruh tingkat pengetahuan responden terhadap keikutsertaan petani bersifat positif, yaitu semakin tinggi tingkat pengetahuan petani maka keikutsertaan petani juga akan semakin tinggi begitu juga sebaliknya.

Variabel besaran premi AUTP $\left(\mathrm{X}_{6}\right)$ memberikan pengaruh pada tingkat motivasi petani mengikuti program AUTP, hal tersebut ditunjukkan oleh nilai koefisien regresi terstandar sebesar $-0,11$ dengan nilai $p<0,25$. Semakin tinggi besaran premi AUTP yang dikeluarkan maka semakin rendah tingkat motivasi petani untuk ikut serta pada program AUTP hal ini ditunjukkan dengan nilai koefisien jalur besaran premi AUTP $\left(\mathrm{X}_{6}\right)$ terhadap tingkat motivasi petani (Y) yaitu negatif $(-0,163)$.

Untuk variabel $\mathrm{X}_{4} \quad$ (tingkat pengetahuan informasi AUTP) juga berpengaruh signifikan terhadap keikutsertaan petani $(Z)$ terhadap program AUTP dengan nilai koefisien regresi terstandar sebesar 0,767 dan $p<0,05$. Hasil informasi di lapangan, bahwa tingkat pengetahuan informasi mengenai AUTP yang diterima oleh petani sangat memberikan pengaruh terhadap penerimaan petani mengenai program AUTP. Hal ini sejalan dengan hasil penelitian yang dilakukan oleh Sayugyaningsih I (2018), bahwa informasi mengenai AUTP sangat mempengaruhi petani untuk ikut serta pada program AUTP. Berdasarkan Tabel output AMOS nilai $\mathrm{P}$ value sebesar 0,014 yang berarti lebih kecil dari 0,05 sehingga dapat disimpulkan bahwa variabel tingkat pengetahuan responden berpengaruh pada tingkat motivasi petani mengikuti program AUTP.

\section{Pengaruh Tingkat pengetahuan AUTP terhadap tingkat motivasi petani}

Tingkat pengetahuan AUTP berpengaruh terhadap tingkat motivasi petani (Y) dengan koefisien regresi terstandar $-0,221$ dan $\mathrm{p}<0,05$. Hal tersebut menunjukkan bahwa, tingkat pengetahuan peserta AUTP terhadap tingkat motivasi bersifat negatif, yaitu semakin tinggi tingkat pengetahuan peserta AUTP maka tingkat motivasi petani semakin menurun begitu juga sebaliknya. Berdasarkan nilai koefisien jalur tingkat pengetahuan peserta AUTP terhadap tingkat motivasi bertanda negatif $(-0,108)$ yang berarti pengaruh tingkat pengetahuan peserta AUTP terhadap tingkat motivasi petani bersifat negatif, yaitu 
semakin tinggi tingkat pengetahuan peserta AUTP maka tingkat motivasi peserta AUTP semakin menurun.

Berdasarkan informasi dari lapangan diperoleh gambaran bahwa informasi yang diterima petani mengenai AUTP termasuk informasi mengenai proses klaim dan pencairan dana klaim, diperoleh selain dari penyuluh juga didapat baik dari sesama anggota kelompok maupun antar anggota kelompok lain yang sudah pernah ikut serta dan mengalami kendala, sehingga petani yang sebelumnya belum pernah ikut karena merasa AUTP adalah program pemerintah yang berpihak pada petani sehingga walaupun banyak mengalami kendala, petani merasa mau tidak mau ikut serta pada program AUTP.

Untuk variabel $\mathrm{X}_{4}$ (tingkat pengetahuan informasi AUTP) juga berpengaruh signifikan terhadap keikutsertaan petani $(Z)$ terhadap program AUTP dengan nilai koefisien regresi terstandar sebesar 0,767 dan $\mathrm{p}<0,05$. Hasil informasi di lapangan, bahwa tingkat pengetahuan informasi mengenai AUTP yang diterima oleh petani sangat memberikan pengaruh terhadap penerimaan petani mengenai program AUTP. Hal ini sejalan dengan hasil penelitian yang dilakukan oleh Sayugyaningsih (2018), bahwa informasi mengenai program AUTP sangat mempengaruhi petani untuk ikut serta pada program AUTP.

Menurut Wahjosumidjo (1987), motivasi merupakan suatu proses psikologis yang mencerminkan interaksi antara sikap, kebutuhan, persepsi dan keputusan yang terjadi pada diri seseorang. Sehingga pada penelitian dapat disimpulkan bahwa sikap petani untuk mau menerima informasi mengenai program AUTP baik yang disampaikan oleh penyuluh pertanian lapangan/PPL atau berdasarkan pengalaman antar sesama anggota kelompok didasari adanya kebutuhan akan jaminan kerusakan yang terjadi pada tanaman padi baik karena banjir, kekeringan maupun serangan OPT (organisme pengganggu tanaman). Selain itu, karena adanya keterikatan dan keharusan dari kelompok sehingga petani mau tidak mau sampai pada keputusan untuk ikut serta pada program AUTP.

\section{Pengaruh besaran premi AUTP $\left(\mathbf{X}_{6}\right)$ terhadap tingkat motivasi petani $(\mathrm{Y})$}

Besaran premi AUTP memberikan pengaruh terhadap tingkat motivasi petani mengikuti program AUTP. Berdasarkan informasi di lapangan petani beranggapan dengan mengeluarkan uang sebesar 36.000 rupiah per musim tanam petani sudah mendapatkan jaminan atas risiko kerusakan yang terjadi. Selain itu, petani beranggapan bahwa biaya premi yang dikeluarkan masih terjangkau sehingga petani mau ikut serta pada program AUTP. Hal tersebut sejalan dengan hasil penelitian sebelumnya bahwa premi mempengaruhi respon petani padi terhadap program AUTP, dimana petani merespon dengan baik program AUTP karena dipengaruhi oleh salah satu faktor yaitu pembayaran premi yang terjangkau oleh petani (Siswadi dan Syakir, 2016). Semakin tinggi besaran premi AUTP yang dikeluarkan maka semakin rendah tingkat motivasi petani untuk ikut serta pada program AUTP hal ini ditunjukkan dengan nilai koefisien jalur besaran premi AUTP $\left(\mathrm{X}_{6}\right)$ terhadap tingkat motivasi petani $(\mathrm{Y})$ yaitu negatif $(-0,163)$.

Berdasarkan informasi di lapangan selain untuk keperluan usahatani modal yang dimiliki oleh petani digunakan untuk keperluan sehari-hari diantaranya untuk makan, keperluan anak untuk sekolah dan kebutuhan lainnya sehingga apabila biaya premi tinggi maka petani akan berfikir ulang untuk ikut serta pada program AUTP. Hasil wawancara di lapangan (Kecamatan Trimurjo Desa Untoro) petani beranggapan bahwa biaya premi yang dikeluarkan masih berat oleh karena itu selain dari subsidi pemerintah dan biaya pribadi, dukungan biaya juga diberikan dari kelompok tani yaitu pembayaran premi yang disubsidi dari kas kelompok sehingga hal tersebut yang menjadi pertimbangan petani untuk ikut serta pada program AUTP. 


\section{Pengaruh Intensitas pendampingan terhadap tingkat motivasi petani}

Intensitas pendampingan berpengaruh signifikan terhadap tingkat motivasi petani dengan nilai koefisien regresi terstandar 0,474 dan $\mathrm{p}<0,05$. Pendampingan perlu dilakukan dengan tujuan untuk mengarahkan petani agar mau dan mampu menerapkan informasi baru (inovasi) di bidang asuransi usahatani padi (AUTP), dari pendaftaran sampai cara melakukan klaim terhadap kerusakan usahatani padi yang dilakukan. Pendampingan AUTP seharusnya dilakukan oleh penyuluh, kelompok tani, pihak Jasindo, petugas POPT, dan Dinas Pertanian baik kabupaten maupun provinsi. Kenyataan di lapangan pendampingan hanya dilakukan oleh penyuluh, sementara untuk pihak Jasindo dan dinas terkait hanya melakukan sosialisasi pada saat pendistribusian alokasi luasan yang mendapat bantuan subsidi pemerintah, selebihnya penyuluh yang berperan pada saat melakukan pendampingan. Berdasarkan penelitian yang dilakukan oleh Maratush (2018); Hasanuddin et al. (2019), dan Nurmayasari et al. (2020), semakin aktif petugas dalam melakukan penyuluhan dan pendampingan kepada petani, kemungkinan petani mengikuti program AUTP akan semakin tinggi. Sejalan dengan hasil penelitian ini, pendampingan yang dilakukan oleh penyuluh mempengaruhi motivasi petani untuk ikut serta pada program AUTP.

\section{Pengaruh Langsung dan Tidak Langsung}

Berdasarkan Tabel 2 dapat diketahui bahwa jumlah total pengaruh $\mathrm{X}_{4}$ terhadap $\mathrm{Y}$ merupakan jumlah yang paling besar ()$, 768)$ artinya pengaruh $\mathrm{X}_{4}$ terhadap $\mathrm{Z}$ adalah pengaruh yang paling kuat. Untuk pengaruh $\mathrm{X}_{8}$ terhadap $\mathrm{Y}$ jumlah pengaruhnya sebesar 0,449 artinya pengaruh $\mathrm{X}_{8}$ terhadap $\mathrm{Y}$ juga merupakan pengaruh yang kuat. Secara rinci nilai pengaruh langsung dan tidak langsung dapat dilihat pada Tabel 2.
Tabel 2.

Pengaruh langsung dan tidak langsung

\begin{tabular}{ccccc}
\hline No & Variabel & $\begin{array}{c}\text { Pengaruh } \\
\text { Langsung }\end{array}$ & $\begin{array}{c}\text { Pengaruh } \\
\text { Tidak } \\
\text { Langsung }\end{array}$ & Total \\
\hline 1 & $\mathrm{X}_{4}-\mathrm{Y}$ & $-0,108$ & 0 & $-0,108$ \\
2 & $\mathrm{X}_{6}-\mathrm{Y}$ & $-0,163$ & 0 & $-0,163$ \\
3 & $\mathrm{X}_{8}-\mathrm{Y}$ & 0,449 & 0 & 0,449 \\
4 & $\mathrm{X}_{4}-\mathrm{Z}$ & 0,767 & 0,001 & 0,768 \\
\hline
\end{tabular}

Berdasarkan output tabel diatas dapat diketahui bahwa besar pengaruh tidak langsung variabel $\mathrm{X}_{4}$ terhadap $\mathrm{Z}$ melalui $\mathrm{Y}$ sebagai berikut:

Pengaruh langsung $=|-0,108|=0,108$

Pengaruh tidak langsung $=\mid-0,108 \mathrm{x}$ $-(0,007) \mid=0,001$

Pengaruh langsung $>$ pengaruh tidak langsung yang bararti $X_{4}$ berpengaruh langsung terhadap $\mathrm{Z}$ tanpa melalaui perantara $\mathrm{Y}$, dengan demikian $\mathrm{Y}$ bukan variabel intervening dalam model hubungan antara $\mathrm{X}_{4}$ dan $\mathrm{Z}$. Hasil penelitian menunjukkan bahwa semakin petani mengetahui lebih jauh dan lengkap mengenai program AUTP termasuk kendala pada saat menjadi peserta dan pada saat pengajuan klaim semakin petani tidak termotivasi namun karena adanya keharusan dan keterikatan kelompok sehingga petani tetap ikut serta pada program selain itu petani juga merasa bahwa program AUTP merupakan program pemerintah yang harus dilaksanakan sehingga dapat disimpulkan bahwa variabel tingkat pengetahuan AUTP berpengaruh langsung terhadap keikutsertaan petani tanpa melalui perantara tingkat motivasi, dengan demikian tigkat motivasi bukan merupakan variabel intervenig dalam model hubungan antara $\mathrm{X}_{4}$ dan Z.

\section{KESIMPULAN}

Berdasarkan hasil penelitian disimpulkan bahwa Motivasi petani mengikuti program AUTP di Kabupaten Lampung Tengah tergolong tinggi dengan faktor-faktor yang mempengaruhi secara langsung meliputi tingkat pengetahuan 
informasi tentang AUTP yang diterima menjadi modal awal petani untuk ikut serta pada program AUTP, besaran premi AUTP yang dikeluarkan petani masih terjangkau karena didukung dari pembiayaan kelompok, dan intensitas pendampingan yang dilakukan oleh penyuluh dalam memberikan pemahaman terkait manfaat dan tujuan dari program AUTP sehingga petani termotivasi ikut serta pada program AUTP.

Kendala yang dihadapi pada saat menjadi peserta AUTP dan pada saat pengajuan klaim meliputi: Penilaian kriteria calon peserta AUTP oleh pihak Jasindo terlalu lama yaitu sekitar satu sampai dua bulan dan banyak tahapan yang harus dilalui, pada saat pengajuan klaim tidak semua petani mendapat ganti rugi padahal sawah sama-sama terkena dampak kerusakan, terbatasnya petugas POPT sehingga berdampak pada lamanya prosedur klaim yang diajukan, dan lamanya proses pencairan dana klaim.

\section{DAFTAR PUSTAKA}

Badan Pusat Statistik. (2014). Lampung Dalam Angka. Badan Pusat Statistik Provinsi Lampung. Bandar Lampung.

Dinas Pertanian Tanaman Pangan dan Hortikultura. (2018). Kinerja Dinas Pertaian Tanaman Pangan dan Hortikultura Provinsi Lampung.

Hasanuddin, T., Viantimala, B., dan Fitriyani, A. (2019). Kinerja Penyuluh Pertanian Lapangan, Kepuasan Petani, dan Produktivitas Usahatani Jagung di Kecamatan Natar, Kabupaten Lampung Selatan. Suluh Pembangunan : Journal of Extension and Development. 1(2): 134-141.

Kementerian Pertanian. 2017. Pedoman Umum Program Asuransi Usahatani Padi. Jakarta.

Listiana, I., Hudoyo, A., Prayitno, R.T., Mutolib, A., Yanfika, H. and Rahmat,
A. (2020). Adoption Level of Environmentally Friendly Paddy Cultivated Innovation in Pringsewu District, Lampung Province, Indonesia. IOP Conf. Series: Journal of Physics: Conf. Series 1467 (2020) 012025. doi:10.1088/17426596/1467/1/012025.

Maratush, A. (2018). Faktor-Faktor yang Mempengaruhi Partisipasi Petani dalam Program Ausransi Usahatani Padi (AUTP) di Kecamatan Jonggol, Kabupaten Bogor. Repository IPB. Bogor.

Mardikanto, T dan Irianto, H. (2010). Metoda Penelitian dan Evaluasi Agribisnis. Universitas Sebelas Maret Press. Surakarta.

Nurmayasari, I., Viantimala, B., Gultom, D.T., Yanfika, H. dan Mutolib, A. (2020). Partisipasi dan Kepuasan Petani Terhadap Kinerja Penyuluh Pertanian di Kecamatan Palas Kabupaten Lampung Selatan. MIMBAR AGRIBISNIS: Jurnal Pemikiran Masyarakat Ilmiah Berwawasan Agribisnis, 6(1): 448459.

Sayugyaningsih, I. (2018). Faktor-Faktor yang Mempengaruhi Petani Mengikuti Asuransi Usahatani Padi (AUTP) di Kecamatan Kaliori Rembang. Skripsi. Departemen Agribisnis IPB. Bogor.

Siswadi, B dan F. Syakir. (2016). Respon Petani Terhadap Program Pemerintah Mengenai Asuransi Usahatani Padi AUTP. Prosiding Seminar Nasional Pembangunan Pertanian. Universitas Islam Malang. Malang.

Soehardjo dan Patong, D. (1999). SendiSendi Proyek Ilmu Usaha Tani. Departemen Imu-Ilmu Sosial. IPB.

Soekartawi. (1999). Agribisnis, Teori dan Aplikasinya. Raja Grafindo Persada. Jakarta.

Wahjosumidjo. (1987). Kepemimpinan dan Motivasi. Ghalia Indonesia. Jakarta. 